\title{
Service Quality, Brand Image and Customer Satisfaction Influence Loyalty (Study on Citilink Airline Passengers)
}

\author{
Agnes Rully Diyah Titis Shinta Dhewi Heri Pratikto \\ Management Study Program, Postgraduate, Malang State University
}

\begin{abstract}
Loyalty is a commitment possessed by customers to remain loyal in using a particular service or product. This study aims to find out: (1) the description of service quality, brand image, customer loyalty and satisfaction on Citilink airline passengers; (2) the influence of service quality, brand image on customer satisfaction on Citilink airline; (3) the influence of customer satisfaction on loyalty on Citilink airline; (4) the direct and indirect influence of service quality, brand image on loyalty through the satisfaction of Citilink airline customers. The data were analyzed using descriptive analysis and path analysis. The population in this study were Citilink passengers at Abdurahman Saleh Airport, Malang with a sample of 380 respondents and using questionnaires as research instruments. The results obtained in this study are (1) service quality and brand image have a positive and significant influence on customer satisfaction on Citilink airline; (2) customer satisfaction has a positive and significant influence on loyalty on Citilink airline; (4) service quality, brand image has a positive and significant influence both directly and indirectly on loyalty through Citilink airline customer satisfaction.
\end{abstract}

Keywords: service quality, brand image, loyalty, customer satisfaction

DOI: $10.7176 / \mathrm{EJBM} / 11-12-08$

Publication date: April $30^{\text {th }} 2019$

\section{Introduction}

In Indonesia, the development of airlines is very rapid, this can be seen since 2001 with the existence of government policy, namely open sky management. Open sky management is a policy that allows foreign flights to enter Indonesia. The increasing need of the Indonesian people at this time in the use of aviation services has caused the emergence of many new airlines.

The number of airplane passengers in Indonesia continues to increase, but this is not a guarantee that airlines can continue to take part in aviation services. This can be seen from a number of airlines that experienced a halt to operations and bankruptcy. In 2013, PT. Metro Batavia (Batavia Air) must be closed after being convicted bankrupt by the court, followed by PT. Merpati Nusantara and PT. Mandala Airliner (Mandala Air). The cause of the problem faced by the three airlines is the same, that is because they continue to lose money and eventually go bankrupt.

To prevent bankruptcy like the three airlines, airlines in Indonesia began to pay attention to consumer demand and of course to fight for market share. One of the company's strategies to remain attractive to the market and retain existing customers is by providing maximum service quality. Maximum service quality is expected to be able to meet customer expectations so that it will create satisfaction and loyalty to the company. This makes the company have a concept to be able to meet the expectations of each customer such as making a slogan that "customer is king" and "your satisfaction is our goal".

One of the airlines that owns such a concept is PT. Garuda Citilink because the company specializes in lowcost carrier (LCC) or low-cost flights. Nowadays, many Indonesian people seem to be interested in the LCC flight system. However, not a few people who underestimate flights with low prices which are often associated with unsatisfactory service quality and security.

According to data from the National Transportation Safety Commission (KNKT), there were 54 cases of accidents from early 2010 to April 2014. A percentage of $18.5 \%$ of these accidents occurred among airlines with the LCC system. Compared with other airlines which are also included in LCC flight systems such as Air Asia and Lion Air, Citilink has better performance and is far from negative judgment. Based on the background of the research above, this study aims to find out:

1.1 the description of service quality, brand image, customer loyalty and satisfaction on Citilink airline passengers

1.2 the influence of service quality, brand image on customer satisfaction on Citilink airline

1.3 the influence of customer satisfaction on loyalty on the Citilink airline

1.4 the direct and indirect influence on service quality, brand image on loyalty through satisfaction on Citilink airline passengers 


\section{Literature Review}

2.1 Quality of Service

According to Kotler (2009), service quality is the totality of features and characteristics of products or services that meet or exceed customer expectations. In the case of service marketing, the quality dimensions that are most often used as references according to Tjiptono (2012) are as follows:

- Reliability

- Responsiveness

- Guarantee

- Empathy

- Physical Evidence

\subsection{Brand Image}

Sangadji (2013) stated that brand image can be considered as a type of association that appears in the minds of consumers when they are remembering a particular brand. According to Ferrinadewi (2008), brand image consists of two components, which are: (1) brand association and (2) support, strength and uniqueness of the brand.

\subsection{Loyalty}

Loyalty is a behavior that is indicated by routine purchases and is based on a decision-making unit (Sangadji, 2013) and to measure loyalty requires several attributes, which are:

- Say positive things about the company to others

- Recommend companies to others

- Consider that the company is the main choice when making service purchases

- Do more business or purchases with companies in the next few years

\subsection{Customer Satisfaction}

Kotler (2006) explains that satisfaction is a feeling of pleasure or disappointment of someone that appears after comparing the performance (results) of a product that is thought to the performance or expected results. According to Lupiyoadi (2001), there are five factors to determine the level of customer satisfaction as follows:

- Product quality Consumers will be satisfied if the results of their assessment of a product indicate that the product they use is of high quality.

- Service quality

Customers will feel satisfied if they get good service and also as expected.

- Emotional

When a customer is using a particular product and brand, the customer will feel proud and gain confidence if the people around him will admire him, so the satisfaction he gets is not from the quality of a product but from the social value that makes consumers satisfied with a brand he uses.

- Price

Customers will feel satisfied when getting a product at a price that is relatively cheaper when compared to other products of the same quality.

- Cost

Customers will feel satisfied if they do not need additional costs or do not need to waste time getting a product or service.

Based on the above theory, the hypothesis proposed in this study are as follows:

H1: Service quality has a positive and significant influence on customer satisfaction.

$\mathrm{H} 2$ : Brand image has a positive and significant influence on customer satisfaction.

H3: Customer satisfaction has a positive and significant influence on loyalty.

H4: Service quality has a positive and significant influence on loyalty.

H5: Brand image has a positive and significant influence on loyalty.

H6: Through customer satisfaction, service quality has a positive and significant influence on loyalty.

H7: Through customer satisfaction, brand image has a positive and significant influence on loyalty.

\section{Research Methods}

This study uses a quantitative approach with descriptive and explanatory types of research. A quantitative approach is an approach that involves the process of collecting, analyzing, interpreting, and writing research results (Creswell, 2009). 


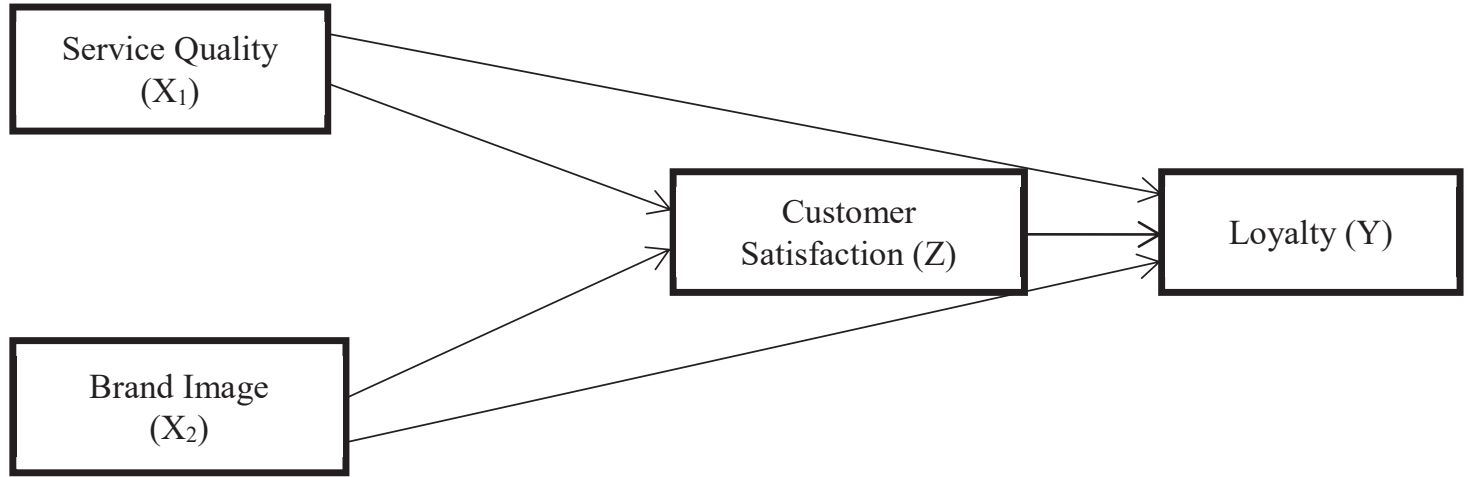

Figure 1. Research Design

3.1 Population and Samples

The population in this study were passengers of the Citilink airline at the Abdurahman Saleh Airport in Malang, East Java, Indonesia. The sampling technique used was proportional random sampling technique with a sample of 380 respondents.

\subsection{Research Instruments}

In this study, the instrument used was questionnaire and the likert measurement method of five scales as the measurement scale. Sugiyono (2015) stated that the likert scale is used to measure attitudes, opinions, and perceptions of a person or group of people.

\subsection{Descriptive Analysis}

Interval class is used to find out categories based on the results of the average value obtained in the respondent's answer.

Table 1. Interval Class

\begin{tabular}{|c|c|c|}
\hline Number & Interval & Category \\
\hline 1. & $1,00-1,80$ & Very Low \\
\hline 2. & $1,81-2,60$ & Low \\
\hline 3. & $2,61-3,40$ & Avarage \\
\hline 4. & $3,41-4,20$ & High \\
\hline 5. & $4,21-5,00$ & Very High \\
\hline
\end{tabular}

\section{Results}

4.1 Description of Respondents

Respondents who filled out the questionnaire in this study were 380 respondents. The dominant respondents were aged 21-30 years or around $32.1 \%$. In this study, the comparison of respondents' sex was almost balanced, that was 196 male respondents or $51.6 \%$ and 184 female respondents or $48.4 \%$. The minority of respondents in this study were retired people, that was 10 people or $10 \%$.

\subsection{Descriptive Analysis}

\subsubsection{Quality of Service}

Table 2. Variable Frequency Distribution of Service Quality

\begin{tabular}{|c|c|c|c|}
\hline Indicators & Item Number & Mean & Category \\
\hline \multirow{2}{*}{ Tangibles } & 1. & 4,33 & Very High \\
\cline { 2 - 4 } & 2. & 4,46 & Very High \\
\hline \multirow{2}{*}{ Realibility } & 3. & 4,18 & High \\
\cline { 2 - 4 } & 4. & 4,32 & Very High \\
\hline \multirow{2}{*}{ Responsiveness } & 5. & 4,10 & High \\
\cline { 2 - 4 } & 6. & 4,07 & High \\
\hline Assurance & 7. & 3,77 & High \\
\cline { 2 - 4 } & 8. & 4,07 & High \\
\hline \multirow{2}{*}{ Empathy } & 9. & 4,11 & High \\
\cline { 2 - 4 } & 10. & 4,04 & High \\
\hline Grand Mean & & $\mathbf{4 , 1 4}$ & High \\
\hline
\end{tabular}

Based on Table 2, it can be seen that the respondents answered that the service quality is high. This can be 
seen from the grand mean value of the service quality variable of 4.14. The highest item value is in item number 2 and the lowest item value is in item number 7 .

4.2.2 Brand Image

Table 3. Variable Frequency Distribution of Brand Image

\begin{tabular}{|c|c|c|c|}
\hline Indicators & Item Number & Mean & Category \\
\hline \multirow{2}{*}{ Strength } & 11. & 3,79 & High \\
\cline { 2 - 4 } & 12. & 3,70 & High \\
\hline Goodness & 13. & 4,06 & High \\
\cline { 2 - 4 } & 14. & 3,80 & High \\
\hline Uniqueness & 15. & 4,05 & High \\
\cline { 2 - 4 } & 16. & 4,25 & Very High \\
\hline \multicolumn{2}{|c|}{ Grand Mean } & $\mathbf{4 , 1 5}$ & High \\
\hline
\end{tabular}

Based on Table 3, it can be seen that the respondents answered that the brand image is high. It can be seen from the grand mean value of the brand image of 4.15. The highest item value is found in item number 16 and the lowest item value is in item number 12 .

4.2.3 Customer Satisfaction

Table 4. Variable Frequency Distribution of Customer Satisfaction

\begin{tabular}{|c|c|c|c|}
\hline Indicators & Item Number & Mean & Category \\
\hline Product Quality & 17. & 4,01 & High \\
\cline { 2 - 4 } & 18. & 3,82 & High \\
\hline \multirow{2}{*}{ Service Quality } & 19. & 3,96 & High \\
\cline { 2 - 4 } & 20. & 3,94 & High \\
\hline \multirow{2}{*}{ Emotional } & 21. & 4,14 & High \\
\cline { 2 - 4 } & 22. & 4,33 & Very High \\
\hline \multirow{2}{*}{ Price } & 23. & 3,93 & High \\
\cline { 2 - 4 } & 24. & 3,67 & High \\
\hline \multirow{2}{*}{ Cost } & 25. & 2,98 & Average \\
\cline { 2 - 4 } & 26. & 3,31 & High \\
\hline Grand Mean & & $\mathbf{3 , 8 0}$ & High \\
\hline
\end{tabular}

Based on Table 4, it can be seen that the respondents answered that customer satisfaction is high. This can be seen from the grand mean value of customer satisfaction of 3.80. The highest item value is in item number 22 and the lowest item value is in item number 26 .

4.2.4 Loyalty

Table 5. Variable Frequency Distribution of Loyalty

\begin{tabular}{|c|c|c|c|}
\hline \multicolumn{1}{|c|}{ Indicators } & Item Number & Mean & Category \\
\hline Repeat Purchace & 27. & 3.48 & High \\
\cline { 2 - 4 } & 28. & 3.53 & High \\
\hline Giving references to other people & 29. & 3.84 & High \\
\cline { 2 - 4 } & 30. & 3.83 & High \\
\hline Rejection of competing products (loyalty) & 31. & 3.52 & High \\
\hline Grand Mean & $\mathbf{3 , 6 4}$ & High \\
\hline
\end{tabular}

Based on Table 5, it can be seen that the respondents answered that loyalty is high. It can be seen from the value of the grand mean of loyalty of 3.64. The highest item value is found in item number 30 and the lowest item value is in item number 27.

\subsection{Path Analysis}

4.3.1 First Model Equation

The first model equation discusses the influence of service quality $\left(\mathrm{X}_{1}\right)$ and brand image $\left(\mathrm{X}_{2}\right)$ on customer satisfaction $(Z)$

Table 6. Sub-Structure Coefficients

Coefficients $^{\mathrm{a}}$

\begin{tabular}{|c|c|c|c|c|c|}
\hline \multirow[b]{2}{*}{ Model } & \multicolumn{2}{|c|}{ Unstandardized Coefficients } & Standardized Coefficients & \multirow[b]{2}{*}{$\mathrm{t}$} & \multirow[b]{2}{*}{ Sig. } \\
\hline & B & Std. Error & Beta & & \\
\hline 1 (Constant) & 18,060 & 2,199 & & 8,213 &, 000 \\
\hline Service Quality &, 250 &, 064 & ,220 & 3,903 &, 000 \\
\hline Brand Image & ,409 &, 080 & 289 & 5,126 &, 000 \\
\hline
\end{tabular}

Dependent Variable: Customer Satisfaction 
In Table 6 , it can be seen that the significance value of the service quality variable $\left(\mathrm{X}_{1}\right)$ and Brand Image $\left(\mathrm{X}_{2}\right)$ is 0.000 which shows that the significance value of the two variables is smaller than alpha of 0.05 . These results provide the conclusion that the first equation, the service quality and brand image have a positive influence on customer satisfaction.

Table 7. First Equation Determination Coefficients

Model Summary ${ }^{b}$

\begin{tabular}{|c|c|c|c|c|}
\hline Model & R & R Square & Adjusted R Square & Std. Error of the Estimate \\
\hline 1 &, $453^{\mathrm{a}}$ &, 205 &, 201 & 3,794 \\
\hline
\end{tabular}

a. Dependent Variable: Customer Satisfaction

b. Predictors: (Constant), Service Quality, Brand Image

In Table 7, it can be seen that the value of $\mathrm{R}$ Square is 0.205 , so that it can be interpreted that the contribution of the influence of service quality variable $\left(\mathrm{X}_{1}\right)$ and brand image $\left(\mathrm{X}_{2}\right)$ on customer satisfaction $(\mathrm{Y})$ is $20.5 \%$, while the remaining $79.5 \%$ is the contribution of other variables not listed in this study. The value of $\mathrm{e}_{1}$ can be searched using the following formula:

$$
\begin{aligned}
\mathrm{e}_{1} & =\sqrt{(1-0.205)} \\
& =\sqrt{(0.795} \\
& =0.891
\end{aligned}
$$

The structural equation is as follows:

$$
\begin{gathered}
Z=\beta_{3} X_{1}+\beta_{4} X_{2}+e_{1} \\
=0.220+0.289+0.891
\end{gathered}
$$

\begin{tabular}{|c|c|c|c|c|c|}
\hline \multirow[b]{2}{*}{ Model } & \multicolumn{2}{|c|}{ Unstandardized Coefficients } & \multirow{2}{*}{$\begin{array}{c}\text { Standardized Coefficients } \\
\text { Beta }\end{array}$} & \multirow[b]{2}{*}{ 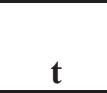 } & \multirow[b]{2}{*}{ Sig. } \\
\hline & $\mathrm{B}$ & Std. Error & & & \\
\hline 1 (Constant) & $-4,963$ & 1,402 & & $-3,541$ &, 000 \\
\hline Service Quality & ,335 &, 038 & ,42 & 8,756 &, 000 \\
\hline Brand Image &, 114 &, 048 &, 11 & 2,363 & ,019 \\
\hline Customer Satisfaction & , 172 &, 030 &, 24 & 5,685 &, 000 \\
\hline
\end{tabular}

4.3.2 Second Model Equation

Table 8. Sub-Structure Coefficients 2

In Table 8, Sub-Structure Coefficients 2, it can be seen that the significance value of the service quality variable $\left(\mathrm{X}_{1}\right)$ and Brand Image $\left(\mathrm{X}_{2}\right)$ is 0.019 and customer satisfaction is 0.000 which shows that the significance value of the three variables is smaller than alpha of 0.05 . These results provide the conclusion that the second equation, the service quality, brand image and customer satisfaction has a positive influence on loyalty.

Table 9. Sub-Structure Summary 2

Model Summary b

\begin{tabular}{|l|r|r|r|r|}
\hline Model & R & \multicolumn{1}{|c|}{ R Square } & Adjusted R Square & Std. Error of the Estimate \\
\hline 1 &, $652^{\mathrm{a}}$ &, 425 &, 420 & 2,227 \\
\hline
\end{tabular}

a. Predictors: (Constant), customer satisfaction, service quality, brand image

b. Dependent Variable: Loyalty

In Table 8 , it can be seen that the $\mathrm{R}$ Square value is 0.425 , so that it can be interpreted that contribution of the influence of service quality variable $\left(\mathrm{X}_{1}\right)$, brand image $\left(\mathrm{X}_{2}\right)$, and customer satisfaction $(\mathrm{Y})$ is $42.5 \%$, while the remaining $57.5 \%$ is the contribution of other variables not listed in this study. The $\mathrm{e}_{2}$ value can be searched using the following formula:

$$
\begin{aligned}
& \mathrm{e}_{2=\sqrt{(1-0.425)}} \\
= & \sqrt{0.575} \\
= & 0.758
\end{aligned}
$$

The structural equation is as follows:

$Y=\beta_{1} X_{1}+\beta_{2} X_{2}+\beta_{5} z+e_{2}$

$=0.429+0.117+0.249+0.758$

The results of path analysis processing with the influence of service quality variable $(\mathrm{X})$, brand image $(\mathrm{X})$ on loyalty (Y) through customer satisfaction $(\mathrm{Z})$ in this study can be seen in more detail in the figure below: 


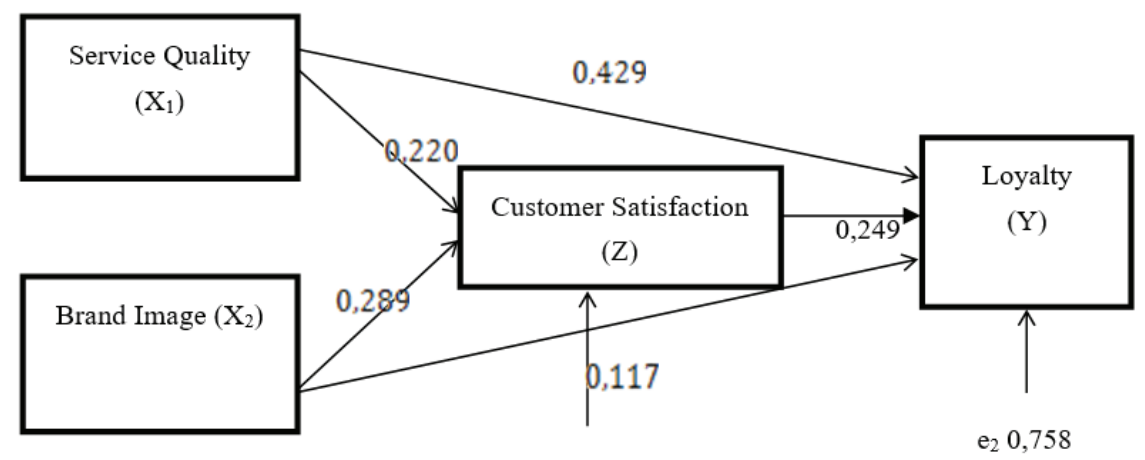

$\mathrm{e}_{1} 0,891$

Figure 2. Results of Path Analysis

Table 10. Results of Path Analysis

\begin{tabular}{|c|c|c|c|c|}
\hline No. & Variables & Direct Influence & Indirect Influence & Total Influence \\
\hline 1. & $\mathrm{X}_{1}$ towards $\mathrm{Z}$ & 0.220 & & 0.220 \\
\hline 2. & $\mathrm{X}_{2}$ towards $\mathrm{Z}$ & 0.289 & & 0.289 \\
\hline 3. & $\mathrm{Z}$ towards $\mathrm{Y}$ & 0.249 & & 0.249 \\
\hline 4. & $\mathrm{X}_{1}$ towards $\mathrm{Y}$ & 0.429 & & 0.429 \\
\hline 5. & $\mathrm{X}_{2}$ towards $\mathrm{Y}$ & 0.117 & & 0.117 \\
\hline 6. & $\mathrm{X}_{1}$ towards $\mathrm{Y}$ through $\mathrm{Z}$ & & $0.220 \times 0.249=0.055$ & $0.429+0.054=0.483$ \\
\hline 7. & $\mathrm{X}_{2}$ towards $\mathrm{Y}$ through $\mathrm{Z}$ & & $0.289 \times 0.249=0.072$ & $0.117+0.249=0.366$ \\
\hline
\end{tabular}

a. First Hypothesis Test

The results of the analysis show a significance value of 0.000 and a path coefficient value of 0.220 which concludes that $\mathrm{H}_{1}$ is accepted and service quality $\left(\mathrm{X}_{1}\right)$ has a positive and significant influence on customer satisfaction $(\mathrm{Z})$. b. Second Hypothesis Test

The results of the analysis show a significance value of 0.000 and a path coefficient value of 0.289 which concludes that $\mathrm{H}_{2}$ is accepted and brand image $\left(\mathrm{X}_{2}\right)$ has a positive and significant influence on customer satisfaction $(\mathrm{Z})$.

c. Third Hypothesis Test

The results of the analysis show a significance value of 0.000 and the path coefficient value is 0.249 which concludes that $\mathrm{H}_{3}$ is accepted and customer satisfaction $(\mathrm{Z})$ has a positive and significant influence on loyalty $(\mathrm{Y})$. d. Fourth Hypothesis Test

The results of the analysis show a significance value of 0.000 and a path coefficient value of 0.429 which concludes that $\mathrm{H}_{4}$ is accepted and service quality $\left(\mathrm{X}_{1}\right)$ has a positive and significant influence on loyalty $(\mathrm{Y})$.

e. Fifth Hypothesis Test

The results of the analysis show a significance value of 0.019 and a path coefficient value of 0.117 which concludes that $\mathrm{H}_{5}$ is accepted and brand image $\left(\mathrm{X}_{2}\right)$ has a positive and significant influence on loyalty $(\mathrm{Y})$.

f. Sixth Hypothesis Test

Service quality has a positive influence on loyalty through customer satisfaction. The hypothesis is obtained from the calculation of the multiplication of the value of beta $(\beta) \mathrm{X}_{1}$ against $\mathrm{Z}$ with the value of beta $(\beta) \mathrm{Z}$ towards $\mathrm{Y}$ of: $0.220 \times 0.24=0.055$

g. Seventh Hypothesis Test

Brand image has a positive influence on loyalty through customer satisfaction. The hypothesis is obtained from the calculation of the multiplication of the value of beta $(\beta) X_{2}$ against $Z$ with the value of beta $(\beta) Z$ towards $Y$ of: $0.289 \times 0.249=0.072$

\section{Conclusion}

\section{Discussion}

5.1 Influence of Service Quality on Customer Satisfaction

Based on the results of the path analysis that has been done, it can be seen that the service quality variables have a positive and significant influence on the satisfaction of Citilink airline customers in Abdurahman Saleh Airport. This statement can be seen from the significance value of $0.000<0,05$, which can be interpreted that the quality of service significantly influences customer satisfaction. In addition, the path coefficient value is 0.220 which indicates that the influence of service quality on customer satisfaction is $22 \%$. The results of this study are in line with previous studies conducted by Wantara (2015), Verriana \& Anshori (2017), and Iskandar (2015) which obtained the results of research that service quality variables significantly influence customer satisfaction. 


\subsection{Influence of Brand Image on Customer Satisfaction}

Based on the results of the path analysis that has been done, it can be seen that the brand image variables have a positive and significant influence on the satisfaction of Citilink airline customers in Abdurahman Saleh Airport. This statement can be seen from the significance value of $0.000<0.05$, which can be interpreted that the brand image significantly influences customer satisfaction. In addition, the path coefficient value is 0.289 which indicates that the influence of brand image on customer satisfaction is $28 \%$. The results of this study are in line with several studies conducted by Rizky et al. (2016) and Andreani et al. (2012) which stated that there is a significant influence on the brand image variables on customer satisfaction.

\subsection{Influence of Customer Satisfaction on Loyalty}

Based on the results of the path analysis that has been done, it can be seen that the customer satisfaction variables have a positive and significant influence on the loyalty of Citilink airline customers at Abdurahman Saleh Airport. This statement can be seen from the significant value of $0.000<0.05$, which can be interpreted that customer satisfaction has a significant influence on loyalty. In addition, the path coefficient value is 0.249 which indicates that the influence of customer satisfaction on loyalty is $24 \%$. The results of this study are in line with the research conducted by Santouridis and Trivellas (2010), Andreani et al. (2012) and Tombokan et al. (2015) which stated that there is a positive and significant influence on customer satisfaction on loyalty.

\subsection{Influence of Service Quality on Loyalty}

Based on the results of the path analysis that has been done, it can be seen that the quality of service has a positive and significant influence on the loyalty of Citilink airline customers at Abdurahman Saleh Airport. This statement can be seen from the significance value of $0.000<0.05$, which can be interpreted that service quality significantly influences customer satisfaction. In addition, the path coefficient value is 0.429 which indicates that the influence of service quality on loyalty is $42 \%$. This research is supported by several studies such as research conducted by Iskandar and Wijaksana (2015) and Verriana and Anshori (2017) which provided findings that service quality has a positive and significant influence on loyalty.

\subsection{Influence of Brand Image on Loyalty}

Based on the results of the path analysis that has been done, it can be seen that the brand image has a positive and significant influence on the loyalty of Citilink airline customers at Abdurahman Saleh Airport. This statement can be seen from the significance value of $0.019<0.05$, which can be interpreted that the brand image has a significant influence on loyalty. In addition, the path coefficient value is 0.117 which indicates that the influence of service quality on loyalty is $11 \%$. The results of this study are in line with the research conducted by Bondesson (2012) which provided findings that brand image has a significant influence on loyalty.

\subsection{Influence of Service Quality on Loyalty through Customer Satisfaction}

Based on the results of path analysis, it is found that the value of indirect influence on service quality on loyalty through customer satisfaction was greater than the value of direct influence. These results indicate that the service quality $\left(\mathrm{X}_{1}\right)$ has an indirectly positive and significant influence on loyalty $(\mathrm{Y})$ through customer satisfaction $(\mathrm{Z})$. This results of the research are in line with research conducted by Pribadi (2014) which obtained results that customer satisfaction can be mediated in the relationship between service quality and loyalty.

\section{7 Influence of Brand Image on Loyalty through Customer Satisfaction}

Based on the results of path analysis, it is found that the value of indirect influence on brand image on loyalty through customer satisfaction is greater than the value of direct influence. These results indicate that the brand image $\left(\mathrm{X}_{2}\right)$ has an indirectly positive and significant influence on loyalty $(\mathrm{Y})$ through customer satisfaction $(\mathrm{Z})$. The result of the research conducted by Andreani et al. (2012) on McDonald's visitors is that if the brand image has an influence on customer satisfaction, then customer satisfaction also has an influence on loyalty. Another study that also supports the result of this research is a research conducted by Butt and Maurtaza (2011) which revealed that customer satisfaction can mediate between brand image and loyalty.

\section{Conclusions and Suggestions}

6.1 Conclusions

Based on the results of the research that has been done, the conclusions can be drawn as follows:

1. Service quality, brand image, customer satisfaction and loyalty on Citilink airline can be categorized as good.

2. Service quality has a positive and significant influence on customer satisfaction on Citilink airline.

3. Brand image has a positive and significant influence on customer satisfaction on Citilink airline.

4. Customer satisfaction has a positive and significant influence on loyalty on Citilink airline.

5. Service quality has a positive and significant influence on loyalty on Citilink airline. 
6. Brand image has a positive and significant influence on loyalty on Citilink airline.

7. There is a positive and significant indirect influence on service quality on customer loyalty through customer satisfaction on Citilink airline.

8. There is an indirectly positive and significant influence on brand image on customer loyalty through customer satisfaction on Citilink airline.

6.2 Suggestions

1. Citilink airline needs to minimize baggage fees which are still considered too expensive by Citilink passengers. In addition to the services provided by the airline, baggage fees are one consideration for prospective passengers in choosing an airline. This needs to be done because currently there are many competing airlines that provide baggage fees at low prices.

2. Citilink airline is expected to maintain the quality of service that has been provided to passengers, so that the passengers always have a good perception or image of Citilink airline. In addition, while maintaining Citilink's services, it is expected to always innovate in all aspects and create updates that cannot be found in other airlines.

3. The Citilink airline must always take care of passengers who are loyal to the airline, this is because the passengers can fly again using the Citilink airline.

4. For further researchers, it is recommended to continue the research in depth and include other variables into the research.

\section{References}

Andreani,Fransisca., Taniaji, Tan Lucy., Puspitasari, Ruth Natalia Made. 2012. Brand Image Towards Loyalty with Satisfaction as a Mediator in McDonald's. Journal Manajement dan Entrepreneurship, vol.14, no. 1, march 2012: $64-71$

Bondesson, N. 2012. Brand Image Antecedents of Loyalty and Price Premium in Business Markets. Business and of Management Research, vol.1, no.1

Butt, Hasnain., Murtaza, Muhammad. 2011. Measuring Customer Satisfaction w.r.t Restaurant Industry in Bahawalpur. European Journal of Business and Management, vol. 3., no.5

Creswell,J.W. 2013. Research Design : Qualitative, Quantitatif, and Mixed Methods Approach (Third Edition). Singapore : SAGE Publication Inc

Ferrinadewi, Erna. 2008. Brand \& Consumer Psychology. Yogyakarta: Graha Ilmu

Iskandar, Priasmoro., Wijaksana, T Indra.2015. Effect of Service Quality on Customer Loyalty through Satisfaction as an Intervening Variable in Transportation Service Users PT. Tara Megah Muliatama (Gema Ripah Taxi) in Bandung City. e-Proceeding of Management : Vol.2, No.3 Desember

Lupiyoadi, Rambat., Hamdani. 2001. Service Marketing Management. Jakarta : Salemba Empat

Kotler, Philip., Keller, Kevin L. 2006. Marketing Management, $12^{\text {th }}$ ed. Upper Saddle River : Pearson Edison

Kotler, Philip., Keller, Kevin L. 2009. Marketing Management, $13^{\text {th }}$ ed. Upper Saddle River : Pearson Edison

Rizky, Yudita. H., Sularso, Raden., Irawan, B., 2016. The Influence of Brand Image on Loyalty through Consumer Satisfaction at the 3Second Distro in Jember. Artikel Ilmiah Mahasiswa

Sangadji, E.M., Sopiah. 2013. Perilaku Konsumen. Yogyakarta: Andi Offset

Santouridis, Ilias., Trivellas,Panagiotis. 2010. Investigating the impact of Service Quality and Customer Satisfaction on Customer Loyalty in Mobile Telephony in Greece. The TQM Journal Vol. 22 No. 3, 2010

Sugiyono.2015. Quantitative, Qualitative Research and $R \& D$ Methods. Bandung : Alfabeta

Tjiptono, Fandy. 2012. Pemasaran Strategik. Yogyakarta : Andi Offset

Tombokan, Feiby., Kawet, Lotje., Uhing, Yantje. 2015. Effect of Service Quality, Brand Image on Satisfaction of Customers of Taplus Users BNI Main Branch Office of Manado. Jurnal EMBA Vol.3 No.3 Sept. 2015, Hal.552-561

Verriana, R.I., Anshori. M.Y. 2017. The Effect of Service Quality on Loyalty through Satisfaction in NU University Surabaya Students. Accounting and Management Journal, Vol. 1, No. 1, July 2017 